an absolute desert. In an ordinary summer's afternoon walk at home one sees more species of plants in flower than I have seen since we entered the river. . . . However, this may improve, as it is now the deatd of winter here, and with the advent of spring I hope to see many new and interesting flowers appear. Zoologically, too, it is disappointing, except in the case of birds. In the lower parts of the river not a bird was to be seen, but now they are rather more frequent, and I have already observed I 6 species, of which I believe about 30 have not before been collected in Argentina. Owing to the desert nature of this part of the Chaco, it: human inhabitants are very few, scattered, and nomadic. We have not seen a single Indian or canoe on the Pilcomayo. But we know they are about, for nearly every day we see their greet fires for hunting all around us, and we occasionally come across a chipped palm, or the remains of an old tolda, the rude shelter which serves them as a tent; now and again, too, we see z. human footprint, sometimes of immense size, impressed upon the muddy margin of a lagoon. So we are always on the alert, the four Britons of the Expedition keeping watch at night, fully armed and wide awake. The four said Britons are Poole, Kenyon (English), Henderson the chief engineer, and myself. When I go away collecting also, as I do eve y day, I always go with loaded revolver and knife-ready for emergencies. For in addition to Indians there are abundance of tigers about, which one has to be prepared for. Yesterday we got an alligator close to the boat, 8 feet long. The alligators here are all small, 8 feet being the largest we have seen. . . .

"As regards food we are on very short rations, being within a month or so of the end of our provisions. The canoe is to be sent down soon, I believe, to hurry up the fresh supplies of provisions, and by it I shall send this letter, although it is very doubtful whether you will ever get it. The health of the men is not good; we have always two or three of the 17 on board ill. I have, however, had excellent health. The only thing disagreeable is the fearful cold. In the mornings the thermometer is often nearly at freezing-point, and I feel quite benumbed. Fortunately, it generally gets a little warmer during the day, the temperature rising in the afternoon to between $70^{\circ}$ and $90^{\circ} \mathrm{F}$. The river-water is regular brine here, quite as salt as sea-water, and when occasionally we run out of fresh water for a few days, it is very disagre able having to take coffee, \&c., made with the salt water. Of ruits here, there are none worth eating. The young parts of the palm-trees are eatable, and we use a good deal of it in order to economize the rice, \&c. I don't expect at all that we can possibly reach Bolivia, and I don't think the river could ever be made navigable."

\section{Protective Colours}

Mr. Poulton, in his book entitled "The Colours of Animals," seeking a reasor: for the glistening metallic colours of many chrysalides, after showing that the colour is probably protective in its origin, states "that it has arisen from the protective re semblance to rough dark surfaces of rocks."

He comes to this conclusion after failing to find other more probable examples of glistening bodies in nature.

Are such not, however, very common (i.) in the slime or mucous covering many of the Invertebrata, and which snails and slugs leave on all surfaces over which they have passed; (ii.) the webs of spiders and their allies, especially if moist ; (iii.) the exudation or excretion of many plants ; (iv.) decomposing bodies ; (v.) the bark of many trees?

Perhaps the commonest places to find glistening chrysalides are on palings, tree trunks, and various plants; all of which structures are usually resplendent with one or more of the above metallic hues, and among which the chrysalides are very hard to find.

May not these more common objects be those of attempted resemblance, rather than the less frequent pieces of broken rock Grosvenor Club, Bond Street, W. Walter K. Sibley.

Mr. SibleY's letter appears to me to contain valuable suggestions as to the neaning of the metallic appearance of certain chrysalides. It is probable that a resemblance to the objects he suggests does aid in concealing the pupæ. Mr. Roland Trimen has similarly concluded that certain brilliant beetles (Cassidida) are protected by resembling drops of dew. At the same time I think that there is some evidence that the metallic appearance of NO. IO92, VOI.. 42$]$ the pupæ of Vanessida may have been originally acquired in order to favour concealment against glittering mineral surfaces. The evidence is as follows:-(I) In shape and character of the surface these pupæ strongly resemble a rough and broken piece of rock. (2) They appear in two forms, resembling grey and weathered as well as fresbly exposed and glittering rock surfaces. (3) When they seek green leaves for pupation they either conceal themselves with the greatest care $(\nu$. atalanta $)$, or a glittering variety of other species is represented by a green variety which is in. conspicuous against the leaves $(V . I 0)$. (4) Another species ( $V$. urtica), which lacks the habit of $V$. atalanta and the green variety of $V$. Io, is, as far as my experience goes, very rarely found on the leaves of its food-plant, and when so found, is, as a rule, diseased.

I mention the chief lines of evidence upon which I have relied in order to show that it was not merely the failure " to find other more probable examples of glittering bodies in nature "which led me to adopt the view alluded to by Mr. Sibley. Although I still consider that my hypothesis is probable, at any rate for the Vanessida, I am convinced that the resemblance to other glittering objects, such as those mentioned by $\mathrm{Mr}$. Sibley, has favoured the development and especially the persistence of the metallic appearance.

September 19.

E. B. Poulton.

\section{The Aryan Cradle-land.}

"IT will be for the benefit of our science," said the President of the Anthropological Section of the British Association, "that speculations as to the origin and home of the Aryan family should be rife; but it will still more conduce to our eventual knowledge of this most interesting question if it be consistently borne in mind that they are but speculations." With the latter, no less than with the former opinion, I cordially agree. And as, in my address on the Aryan cradle-land, in the Anthropological Section, I stated a greater variety of grounds in support of the hypothesis of origin in the Russian steppes than has been elsewhere set forth, I trust that I may be allowed briefly to formulate these reasons, and submit them to discussion.

(I) The Aryans, on our first historical knowledge of them, are in two widely separated centres, Transoxiana and Thrace. To Transoxiana as a secondary centre of dispersion the Eastern Aryans, and to Thrace as a secondary centre of dispersion the Western Aryans, can, with more or less clear evidence, or probable inference, be traced, from about the fourteenth or perhaps fifteenth century B.C. ; and the mid.region north-west of Transoxiana and north-east of Thrace-and which may be more definitely described as lying between the Caspian and the Euxine, the Ural and the Dnieper, and extending from the forty-fifth to the fiftieth parallel of latitude-suggests itself as a probable primary centre of origin and dispersion.

(2) For the second set of facts to be considered reveal earlier white races from which, if the Aryans originated in this region, they might naturally have descended as a hybrid variety. Such are the facts which connect the Finns of the north, the Khirgiz and Turkomans of the east, and the Alarodians of the south, with that non-Semitic and non-Aryan white stock which have been called by sıme Allophyllian, but which, borrowing a term recently introduced into geology, may, I think, be preferably termed Archaian; and the facts which make it probable that these white races have from time immemorial met and mingled in the South Russian steppes. Nor, in this connection, must the facts be neglected which make great environmental changes probable in this region at a period possibly synchronous with that of Aryan origins.

(3) In the physical conditions of the steppes characterizing the region above defined, there were, and indeed are to this day, as has been especially shown by Dr. Schrader, the conditions necessary for such pastoral tribes as their language shows that the Aryans primitively were ; while, in the regions between the Dnieper and the Carpathians, and between the Oxus and the Himalayas, the Aryans would, both in their south-western and south-eastern migrations, be at once compelled and invited, by the physical conditions encountered, to pass at least partially from the pastoral into the agricultural stage.

(4) The Aryan languages present such indications of hybridity as would correspond with such racial intermixture as that supposed; and in the contemporary language of the Finnic groups Prof. de Lacouperie thinks that we may detect survivals of a former language presenting affinities with the general characteristics of Aryan speech. 